\title{
The Importance of Individual Technology Factors for Adoption of Internet Banking
}

\author{
Alaa A. Alkafagi ${ }^{1} \quad$ Anas A. Salameh ${ }^{2 *}$ Ibrahim A. Abu AlSondos ${ }^{3}$ \\ 1.Ministry of Finance, Rafidain Bank \\ 2.Department of Management Information Systems, College of Business Administration, Prince Sattam Bin \\ Abdulaziz University, Alkharj, Saudi Arabia \\ 3.Department of Management Information Systems, College of Administrative Sciences, Applied Science \\ University, Bahrain
}

\begin{abstract}
The main objective of this study is to find the factors that motivate customers to adopt Internet banking services. It is concerned with an empirical investigation of individual factor technology that could predict successful IBSA. Survey method is used questionnaires are administered on 535 persons in public university staffs already using internet banking services. The findings reveal that individual factors technology is high significant (IFT). It shows four significant relationships between Internet technology literacy toward internet banking adoption $(\beta=.466, \quad \mathrm{~T}=5.672, \quad \mathrm{P}<.000)$; Resistance to change toward internet banking adoption $(\beta=-0.118 \mathrm{~T}=2.262$, $\mathrm{P}<.024)$; Risk of technology toward internet banking adoption $(\beta=-\mathrm{O} .125, \mathrm{~T}=3.838, \quad \mathrm{P}<.000)$ and Anxiety of technology toward internet banking adoption $(\beta=-0.172, \mathrm{~T}=4 . .821, \mathrm{P}<0.000)$. The results are discussed in the context of internet banking adoption / actual usage.
\end{abstract}

Index Terms- Individual factors technology, Internet technology literacy, SEM

DOI: $10.7176 / \mathrm{EJBM} / 11-36-01$

Publication date: December $31^{\text {st }} 2019$

\section{INTRODUCTION}

In the recent time, the rapid diffusion of internet has brought a radical change in delivery of financial services. Consequently, this has also made usage of internet banking to be indispensable especially with the recent high rate of competition among banks globally. Internet banking refers to web based financial services being rendered by banks to their numerous customers. The ubiquitous and rapid increase in the availability information and communication technologies (ICTs) has equally influenced the way banks are currently serving their customers (Hoehle et al., 2012). Globally, banking organizations are the largest users of IT while they equally largest amount on upgrading IT facilities.

Steady and advanced economic growth and financial systems and economic growth are essentially connected. In fact, empirical research has shown that countries with well-developed financial systems often grow very fast. This is obvious as resources that are prudently and effectively distributed by the financial system can boost economic growth; increase rate of production, give equal opportunity, and decrease rate of poverty (World Bank, 2012; Alsabaah 2014; CBI, 2012). In addition, it is very essential for job creation, encourage foreign and local investment, and accelerate technology sector development which can lead to economic growth and development (Report of U.S.A. Agency for International Development, 2009).

In view of the above, Jasim and Mubark (2010) argued that technological factor such as small number of internet users (only 9\%) is responsible for the decline of customers' adoption of IBS (Report of United Nations ESCWA, 2010, p.19). This therefore indicates that person are not competent in the usage and applications of internet technology with regards to IBS (Alhammadany \& Heshmati,2011b,p. 1). Based on this therefore, it sounds very logical that researchers should study those individual technological factors that can impact IBSA (Shendy, 2011). In this regard, Ezzi, (2014) argues that in view of the stated challenges, and other factors such as poor perception and lack of adequate technological skills, the tendency that adoption of internet banking in Gulf countries generally may continue to decline is very high. Importantly, these reasons might continue to hamper the adoption IBS because the level of Individual factors technology are suboptimal in these countries

\section{LITERATURE REVIEW}

Personality or Individuality is a concept that describes the affective and cognitive attributes of individuals which assist the individual in adjusting certain events, situations and people which they encountered in the course of their life (Abushanab et al., 2010; Zmud, 1979). Dillon and Watson (1996) while exploring individual differences regarding human computer interaction and user analysis reached a conclusion that existing research on these issues are deficient in three areas: a) humans have tendency of exhibiting different and contradictory styles depending on the situations they found themselves; $b$ ) that the scopes which previous researches identified are highly superficial and must be refined; and c) that styles might be positively or negatively linked. Literature also lend credence that features of individual are strong predictor of actual usage (Venkatash et al., 2003), as 
depict in Figure 1.

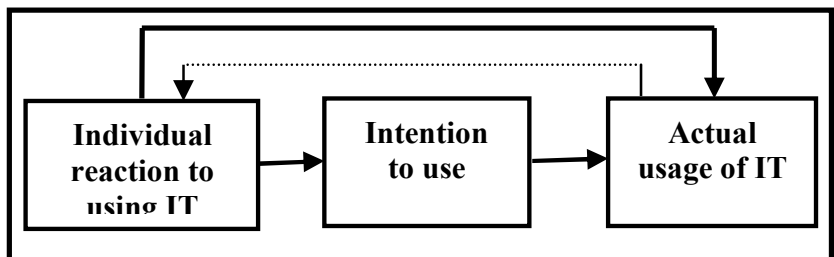

Figure 1: Basic concept underlying user

The study of influence of individual factors technology on the adoption of internet banking is still very sparse. Even though past researchers have made several attempts to investigate the individual factors technology (Agarwal \& Prasad, 1998; Agarwal, Prasad \& Zanino, 1996; Zmud, 1979; Venkatesh et al., 2003) the influence of the individual factors technology on the adoption of internet banking is still lacking in the literature. The research framework proposed in this paper as shown in Figure 2.

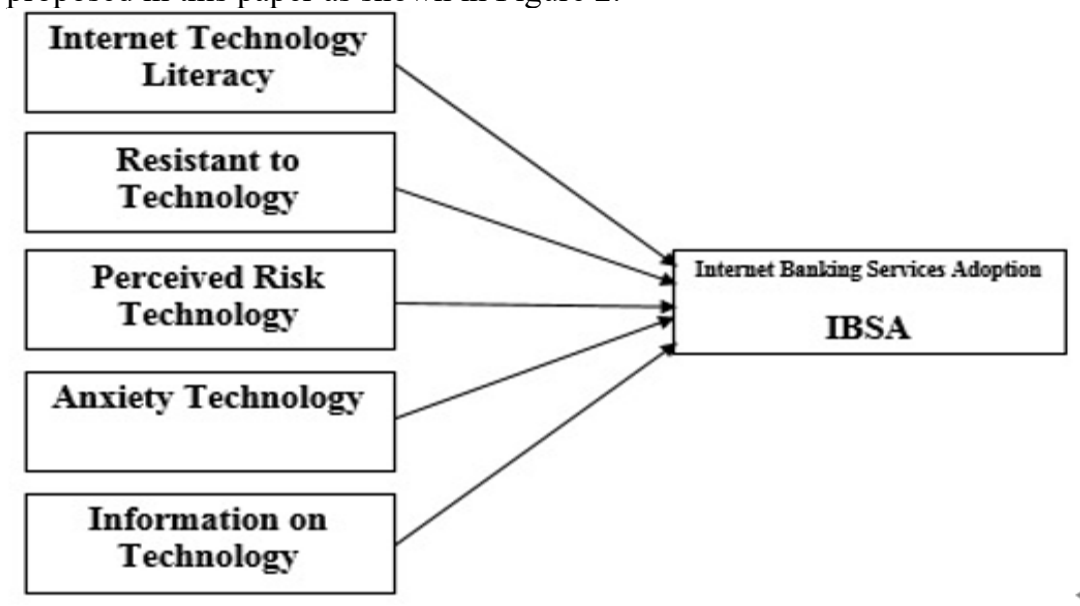

Importantly, a parallel line exists between internet banking and online consumer behavior based on TPB. Li et al. (1999) in this instance posits that internet experience, convenience, perceived accessibility and utility impact online consumer behavior strongly. Extant literature also assert that literacy about internet technology is a major factor influencing the decision to make online purchasing in Thailand through social media. This therefore indicates that the possibility of increasing the rate of adoption will be high if people has adequate knowledge about issues surrounding technology usage as such will boost their understanding and application of it (Avirutha, 2012). This assertion is equally supported by other scholars by noting that inadequate of internet or computer knowledge is one of the likely reasons for not adopting IBS (Karjaluoto et al., 2002)

Further, customers' are still very hesitant in changing from brick and mortal banking to IBS (Sathye, 1999; Wallis, 1997; Alagheband, 2006; Al-Somali et al. 2009). Ideally, customers can transist or change from one form of banking to another especially if their needs are met. However, Daniel (1999) found that customers still maintain high level of inertia to switch from traditional banking to IBS. As noted by Al-Somali, Gholami and Clegg (2009) in their study of 400 customers in the Kingdom of Saudi Arabia (KSA), customers resistance is still one of the major factors inhibiting adoption of internet banking.

Asides, other researches have also indicated that perception of risk impacts the behavior of customers (e.g., Sweeney et al., 1999; Grewal et al., 1994). This perception is divided into two components of uncertainty, that is, the possibility of unfavorable outcomes and effects which refer to the importance of a loss (Cox \& Rich, 1967; Bauer, 1960). The study of Chang and Tseng (2011) which surveyed 332 respondents found that perceived risk also has strong influence on consumer's purchase intention. This therefore indicates that it is essential for online retailer to understand the needs of their customers while every effort is made in providing improved quality service at reduced shopping costs/risks. This is also in line with the position of the study of Fitzgerald and Kiel (2001) that explored online purchasing behavior by inculcating perceived risk as one of the variables that can impact attitude of consumers. The result of this study also indicates risk significantly influenced the behavior of adopters. Moreover, Pavlou (2003) also explored the perception of risk while predicting intention to transact in an e-commerce environment. In this study, Perceived risk was found to be significant but negatively related to customers behavior (Taylor, 1974). This therefore indicates that the higher the perception of risk, the lower the tendency that customers will buy the product (Taylor, 1974). 
Anxiety was further explored as part of the social cognitive theory and as one of the predictors of outcome expectation or usage. Scholars have recognized anxiety as part of part of personality traits as it accounted for in the individual differences literature (Agarwal, Sambamurthy \& Stair, 2000; Thatcher \& Perrewe, 2002). Importantly, perceived anxiety has been found to be statistically significant since it outweighs other factors while explaining the actual usage behavior of the e-filing system in the Malysian contexts (Ibrahim, 2012). This therefore justifies the inclusion of anxiety as a predictor of IBSA, and as part of the composition of individual traits of using technology (IB).

One of the common important factors that are often considered while making online transaction decision is the quantity of information the customers have about technology. According to Guiltinan and Donnelly (1983) the quantity of information concerning the advantages or uses of a product/service", is a strategy that can be used to promote certain service/product. This is also in line with the Wallis Report (1997) which states that consumers will prefer those financial services and suppliers which give the best value for money as well as provide information about the profit. Howard and Moore (1982) also argued that consumers must be conversant with the new brand before adopting it. It is therefore essential to create awareness of the service or product among consumers before adoption can take place. Howcroft et al. (2002) also emphasized that lack of information about the benefits of IBS could negatively influence the behavior of customers. This is also in line with the findings of Al-Somali et al. (2009) where TAM factors were used to investigate IBSA. The finding of this study reveals that information about the benefits of IBS has significance influence on IBSA.

\section{Hypothesis Development}

Hypothesis is a proposition of the logically guessed relationship between two or more variables, which is based on the theory of theoretical framework that is empirically testable to find the expected solution to the problem statement (Sekaran \& Bougie, 2010; Zikmund, Babin, Carr, \& Griffin, 2010). Therefore, the position of this study is that when IBSA is successfully implemented, continuous adoption of Internet banking is possible.

In view of the above, personality dimensions have been regarded as one of the factors that can usage behavior because it is related to individual personality. This further implies that affective and cognitive structures of individuals can assist them to adjust in dealing with people, situation and events. Based on literature, these dimensions are believed to be significant in influencing customers toward IBSA.

Importantly, most of the previous studies were carried in different settings (Compeau \& Higgins, 1995; Venkatesh,et al., 2003), while the studies that look into individual factors of technology such as anxiety, resistance to technology, risk technology and information on technology in IBSA generally are very sparse. However, the researchers has not found any study in IBSA setting that included this dimension as an antecedent of IBSA. Since IBS is a type of online technology services, the emphasis is played on the importance of these individual factors and how they influence individual behavior towards adoption of IBSA. In this view, it is the objective of this study to examine these dimensions: resistance to technology, internet technology literacy, risk of technology, information on technology, anxiety about technology, and the influence on IBSA.

Based on the previous arguments relating to individual factors dimension, the following hypotheses are posited:

H1: Internet and Technology literacy positively influence customers' adoption of Internet banking.

H2: Resistance to technology significantly impacts on customers' adoption of Internet banking.

H3: Risk of technology (RT) negatively influences customers' adoption of Internet banking.

H4: Anxiety of technology (AT) negatively influences customers adoption of Internet banking.

H5: The amount of Information on internet banking (IOI) positively influences customers adoption of Internet banking.

\section{METHODOLOGY}

The central objective of this study is to examine the influence of individual factors technology on the adoption of internet banking in the gulf public universities sector. These universities are located in in the Middle, Northern, and South geographic region (Mohsen, 2011).

In conducting this study, a quantitative survey through the usage of a structured questionnaire was used in collecting the primary data for this study. In addition, a probability sampling technique was used as the technique gives every individual targeted response an equal opportunity to be selected (Salkind, 2003). This technique does allow any form of bias regarding the sampling process (Cavana, 2001) as it also ensures high generalizability of the result. In conducting the study, eight hundred questionnaires were directly distributed while only five hundred and thirty five $(67 \%)$ were eventually used for analysis. Direct distribution of the questionnaire because the postal system is not reliable.

In testing the variables of this study, the researchers adopted/adapted measurement scale for each construct from past studies. In view of this, a 4-items scale of IBSA is adapted from Raman et al., (2008). Internet technology literacy 5-items scale was adapted from Nasri (2011); and Poon (2008). Resistance to technology based on four items scale was adapted from Al-somail et al. (2009). A four item scale on perceived risk of 
technology, was adapted from Grabner-Krauter and Faullant (2008); and Abushanab \& Pearson (2010), while the scale of Anxiety about technology was adapted from Abushanab and Pearson (2010); and Ibrahim (2012). Lastly, four items scale for Information on technology was adapted from Al-somali et al (2009). All of the measurement scales are tested using 7-point Likert type.

\section{ANALYSIS OF RESULTS}

To analyze the result of this study, partial least-squares (PLS) analysis technique was used. With the PLS SEM, the researchers was able establish the measurement model for the purpose of determining the internal consistency reliability and construct validity of the items scales used to operationalize the study variables. The PLS was also used for testing of hypotheses.

Validation of the Measurement Scale: In the data analysis stage, a two-phase approach as recommended by Anderson and Gerbingin (1998) was employed in order to assess the reliability and validity of the measures before using them in the research model. In the first phase, the measurement model is analyzed, while the second phase tests the structural relationships among latent constructs. The measurement model helps to establish internal consistency reliability, convergent and discriminant validity of the research instruments. This is in essence signifies the strength or otherwise of the intending model (Fornell, 1982). As indicated in Table 1, all reliability measures were above the threshold of 0.70 as an indication of adequate internal consistency (Hair, 2010; Nunnally \& Bernstein, 1994).

Table 1 Convergent Validity Analysis

\begin{tabular}{|c|c|c|c|c|c|}
\hline Constructs & Items & Loading & Cronbachs Alpha & Composite Reliability & AVE \\
\hline \multirow[t]{4}{*}{$\mathrm{AOT}$} & AOT1 & 0.789 & 0.797 & 0.812 & 0.678 \\
\hline & AOT2 & 0.517 & & & \\
\hline & AOT3 & 0.648 & & & \\
\hline & AOT4 & 0.897 & & & \\
\hline \multirow[t]{4}{*}{ IBSA } & IBSA1 & 0.880 & 0.748 & 0.841 & \\
\hline & IBSA2 & 0.865 & & & \\
\hline & IBSA3 & 0.471 & & & 0.582 \\
\hline & IBSA4 & 0.763 & & & \\
\hline \multirow[t]{4}{*}{ IOT } & IOT1 & 0.574 & 0.732 & 0.736 & \\
\hline & IOT2 & 0.509 & & & \\
\hline & IOT4 & 0.957 & & & 0.528 \\
\hline & PB5 & 0.796 & & & \\
\hline \multirow[t]{2}{*}{ RTT } & RTT1 & 0.611 & 0.453 & 0.761 & \\
\hline & RTT4 & 0.936 & & & \\
\hline \multirow[t]{5}{*}{ RT } & PRT1 & 0.792 & 0.850 & 0.892 & 0.625 \\
\hline & PRT2 & 0.821 & & & \\
\hline & PRT3 & 0.876 & & & 0.674 \\
\hline & PRT4 & 0.792 & & & \\
\hline & RTT4 & 0.936 & & & \\
\hline \multirow[t]{4}{*}{ TIL } & TIL1 & 0.716 & 0.755 & 0.833 & \\
\hline & TIL2 & 0.677 & & & \\
\hline & TIL4 & 0.823 & & & 0.556 \\
\hline & TIL5 & 0.759 & & & \\
\hline
\end{tabular}

In addition, the convergent and discriminate validity of the constructs very satisfactory and in line with the recommendation of Fornell \& Larcke, (1981). A convergent validity is said to valid when the average variance extracted (AVE) of the constructs is at least 0.5 (Fornell \& Larcke, 1981). This is also applicable to convergent validity as the items loading on their associated factors should be above 0.556 .

However, for discriminate validity to be satisfactory, the calculated AVE from the construct should be higher than the variance shared between a particular construct and other constructs in the model (Hair et al., 2010). The discriminant validity of constructs, with correlation among constructs and the square root of AVE on the diagonal. All indicators load more highly on their own constructs than on other constructs. All these results point to the convergent and discriminant validity of our instrument items.

\section{Examination of Research Hypotheses}

The results of the analysis that are obtained from PLS are used to accept or reject the proposed hypotheses. This was achieved by considering the significance of the standardized path coefficient beta weight $(\beta)$ which explains the level of relationship among the constructs. The $\left(\mathrm{R}^{2}\right)$ value, reveals the amount of variance in endogenous variable which the independent variables explain. The path coefficients and $\mathrm{R}^{2}$ show the quality of the model. The $\mathrm{R}^{2}$ shows the predictive ability of the model while it is similarly interpreted in the same way regression 
analysis $\mathrm{R}^{2}$ is interpreted. In line with the arguments of Chwelos et al. (2001), the path coefficients should be significant and consistent with expectations. In order to obtain statistical significance level of the paths, this study applied the bootstrapping techniques embedded with the SmartPLS2.0.

Therefore, for individual technology factors, all the 5 Hypotheses are supported while only one is not. The result reveals that technology and Internet literacy significantly and positively influence adoption of Internet banking at the $0.01(\beta=466, \mathrm{t}=5.672, \mathrm{p}<0.01)(\mathrm{H} 1)$. Resistance to change significantly and negatively influences customers' adoption of Internet banking at the $0.01(\beta=-0.118, \mathrm{t}=2.262, \mathrm{p}<0.01(\mathrm{H} 2)$, Risk of technology significantly and negatively influence customers' adoption of Internet banking at the $0.01 \quad(\beta=-$ $0.125, \mathrm{t}=3.818, \mathrm{p}<0.01)$. Anxiety of technology has a significant and negative influence on customers' adoption of Internet banking at $0.01(\beta=-0.172, t=4.821, p<0.01)($ H4). Finally, The amount of Information on internet banking has no influence on customers' adoption of Internet banking $(\beta=0.082, \mathrm{t}=1.197, \mathrm{p}>0.01)$, which mean that the H5 is unsupported, as reported in Table 2.

Table 2: Assessment of the structural model

\begin{tabular}{llllll}
\hline \multicolumn{1}{c}{ H } & \multicolumn{1}{c}{ Path Coefficient } & \multicolumn{1}{c}{ (STERR) } & \multicolumn{1}{c}{ T value } & \multicolumn{1}{c}{ P value } & \multicolumn{1}{c}{ Decision } \\
\hline TIL -> IBSA & 0.466 & 0.082 & 5.672 & $0.000^{* * *}$ & Supported \\
RTT -> IBSA & -0.118 & 0.052 & 2.262 & $0.024 * *$ & Supported \\
PRT -> IBSA & -0.125 & 0.033 & 3.818 & $0.000^{* * *}$ & Supported \\
AOT -> IBSA & -0.172 & 0.036 & 4.821 & $0.000^{* * *}$ & Supported \\
IOT -> IBSA & 0.082 & 0.068 & 1.197 & 0.116 & Not Supported \\
\hline
\end{tabular}

\section{Discussion and Conclusion}

This study was carried out with the purpose of examining the influence of the individual technology factors on the adoption of internet banking. The findings of the study show that four out of five hypotheses were statistically supported. This result was achieved by applying partial least squares structural equation modeling (PLS-SEM) as well as SPSS. PLS SEM is a relatively new analytical technique being used by the contemporary researchers.

Succinctly, this study provides empirical evidence that internet technology literacy significantly influences the adoption of internet banking and which makes $\mathrm{H} 1$ to be accepted. This result is in tandem with the findings of other studies (Nasri, 2011; Karjaluoto et al., 2002). As argued by Avirutha (2012), customers who have technical knowledge of the internet are more inclined to use internet banking than otherwise. This is also in line with the position of Karjaluoto et al. (2002) who found that that prior Internet technology experience significantly impacts attitude towards and actual usage of online banking. Additionally, the result of this study also shows that resistance to technology has significant but negative influence on IBSA thereby making $\mathrm{H} 2$ to be supported. This outcome agrees with existing empirical findings (Alsomali et al., 2009; Avirutha, 2012; Sathye, 1999). The implication this is that even though the customers still maintain some level of confidence in their banks, it is evident that majority of them are still hesitant about usage of online banking. This is obvious as the empirical evidence of this study has shown that when the customers are not too sure about the safety of their financial transactions, they tend to be apprehensive and which subsequently has some negative impact on the usage of online banking.

Further, the empirical evidence also shows that perceived risk has significant but negative influence on IBSA thereby making (H3) to be supported and in line with the findings of other studies (Farzianpour et al., 2014; Nasri, 2011, Avirutha, 2012). This finding reveals that when the users of online banking perceived high level of uncertainty, their rate of usage of online banking may be reduced. Relating to (H4), the finding of our study reveals that this hypothesis is supported. Similar results have been reported by previous studies in different contexts (Compeau\& Higgins, 1995; Ibrahim, 2012). The implication of this is that people with high anxiety are averse to usage of online banking. Surprisingly however, the relationship between amount of information on technology and adoption of internet banking was found to be insignificant and which makes H5 not to be supported. This result is similar to that of Nasri, (2011) and Prakash \& Malik (2008) in the IBSA setting.

As a recap, and based on the findings of this study, it is essential that banks should pay significant attention to issues that can enhance customers experience through the development of an alternative banking platform that can make interaction with customers to be easy and friendlier as this will complement the utilitarian aspect of internet banking. Importantly, this will help the banks to build a strong relationship with their customers while the banks will enjoy goodwill. In addition, since security situation is extremely sensitive, it is very necessary that the banks should hire services of expatriate that can help to improve the security situation the online banking platform.

\section{REFERENCES}

[1] AbuShanab, E., Pearson, J., \&Setterstrom, A., (2010). Internet banking and customers' acceptance in Jordan: The unified model's perspective. Communications of the Association for Information Systems. 26 (23), 493- 
524.

[2] Agarwal, R., Prasad, J., \&Zanino, M. C., (1996). Training experience and usage intention: a field study of a graphical user interface. Int. J. Human-Computer Studies, 45(2), 215-241.

[3] Akinci, S., Aksoy, S. and Atilgan, E., (2004). Adoption of internet banking among sophisticated consumer segments in an advanced developing country, International Journal of Bank Marketing, 22(3), 212-232.

[4] Alagheband, P., (2006). Adoption of electronic banking services by Iranian customers. Master's thesis, Luela University of Technology, Sweden

[5] Al-Gahtani, S. S., (2004).Computer technology acceptance success factors in Saudi Arabia: an exploratory study. Journal of Global Information Technology Management, 7(1), 5-29.

[6] Al-majali, M., \& Mat, N. K. N., (2011). Modeling the antecedents of internet banking service adoption (IBSA) in Jordan: A structural equation modeling (SEM) approach. Journal of Internet Banking and Commerce, 16(1), 1-15.

[7] Al-majali, M. M., \& Mat, N. K. N., (2010), Applications of planned behavior theory on internet banking services adoption in Jordan: Structural equation modeling approach. China-USA Business Review, 9(12), 112

[8] Alnsour, M., \& Al-Hyari, K., (2011). Internet Banking and Jordanian Corporate Customers: Issues of Security and Trust. Journal of Internet Banking and Commerce, 16(1), 1-14

[9] Al-Somali, S. A., Gholami, R., \& Clegg, B., (2009). An investigation into the acceptance of online banking in Saudi Arabia. Technovation, 29(2), 130-141.

[10] Anderson, J.C., \& Gerbing, D.W., (1988).Structural equation modeling in practice: A review and recommended two-step approach. Psychological bulletin, 103(3), 411.

[11] Avirutha, A., (2012), The Adoption of Social Media to Enhance Performance of Small and medium Businesses in Thailand. Business and Information, Sapporo, 3(5)164-182.

[12] Awamleh, R., \&Fernandes, C., (2006). Diffusion of Internet banking amongst educated consumers in high income non-OECD country. Journal of International Banking and Commerce, 11(3).

[13] Chang, E. C., \& Tseng, Y. F., (2011). Research note: E-store image, perceived value and perceived risk. Journal of Business Research. 10(6), 1-7.

[14] Chin, W.W., (1998).The partial least squares approach for structural equation modeling.

[15] Chwelos, P., Benbasat, I., and Dexter, A., (2001). Empirical Test of an EDI Adoption Model,Information Systems Research (12:3), 304-321.

[16] Compeau, D. R., \& Higgins, C. A., (1995). Computer self-efficacy: Development of a measure and initial test. MIS quarterly, 19(2), 189-211.

[17] Cooper, R. G., (1997). Examining some myths about new product winners. The Human Side of Managing Technological Innovation, Oxford, 550-560.

[18] Dadayan, L., \& Ferro, E., (2005). When technology meets the mind: A comparative study of the technology acceptance model. International conference on electronic government, 35 (91), 137-144.

[19] Foon, S. Y., \&Fah, Y. C., (2011) Internet banking adoption in Kuala Lumpur: an application of UTAUT model.International Journal of Business and Management, 6(4), 161-167.

[20] Fornell, C., A,(1982), Second Generation of Multivariate Analysis: Measurement and Evaluation 2(5), Praeger Publishers.

[21] Fornell, C., \& Larcker, D.F.,(1981). Evaluating structural equation models with unobservable variables and measurement error. Journal of marketing research, 39-50.

[22] Frankfort-Nachmias, C. \&Nachmias, D., (1996). Research Methods in the Social Sciences, 5th ed. St. Martin's Press: London.

[23] Guiltinan, J.P. and Donnelly, J.H., .(1983) The use of product portfolio analysis in bank marketing planning, in Shanmugam and Burke (Eds), Management Issues for Financial Institutions, $p .5$.

[24] Grabner-Kraeuter, S. \&Faullant, R., (2008). Consumer acceptance of internet banking: The influence of internet trust. International Journal of Bank Marketing, 26(7), 483-504.

[25] Hair, JF, Black, WC, Babin, BJ, \& Anderson, RE., (2010). Multivariate data analysis: a global perspective: Pearson Education.

[26] Harrison, D.A., Mykytyn, P.P. \&Riemenschneider, C. K., (1997). Executive decisions about adoption of information technology in small business theory and empirical tests. Information Systems Research, 8(2), 171-195.

[27] Hernandez, J. M. C., \&Mazzon, J.A., (2007)Adoption of internet banking: proposition and implementation of an integrated methodology approach. International Journal of Bank Marketing, 25(2), 72-88.

[28] Hoehle, H., Scornavacca, E., \& Huff, S., (2012). Three decades of research on consumer adoption and utilization of electronic banking channels: A literature analysis.Decision Support Systems. 9(8)1-1.

[29] Hong,Y.,Teh, B.,Vinayan, G.,Soh, C.,Khan,N., \&Ong, (2013).T., Investigating the Factors Influence Adoption of Internet Banking in Malaysia: Adopters Perspective. International Journal of Business and 
Management; 19(8), 24-31.

[30]Howard, J., \& Moore, W. (1982). Changes in consumer behavior over the product life cycle. Readings in the Management of Innovation, 128(5).

[31] Howcroft, B., Hamilton, R., \& Hewer, P., (2002). Consumer attitude and the usage and adoption of homebased banking in the United Kingdom. International Journal of Bank Marketing, 20(3), 111-121.

[32] Ibrahim, I., (2012). Factors Underpinning Usage Behavior of an Electronic Filing System: The Case of Malaysian Personal Taxpayers. Australian Tax Teachers Association (ATTA) ConferenceRetrieved on sept.2012 from: http://sydney.edu.au/law/parsons/ATTA/docs_pdfs/conference_papers/Ibrahim.pdf

[33] ITU, eyes USD2bn for fourth wireless license. March 16, 2011. Retrieved on 10/2/2012 from:

[34] ITU,Trio of GBI developments reported (2012). Retrieved on 5 April 2013

[35] Laforet, S., \& Li, X., (2005), Consumers' attitudes towards online and mobile banking in. China. International Journal of Bank Marketing, 23(5), 362 - 380.

[36] Lohmöller, J.B., (1989). Latent variable path modeling with partial least squares: Physica-Verlag Heidelberg,

[37] Lee, M. C., (2009).Factors influencing the adoption of internet banking: An integration of TAM and TPB with perceived risk and perceived benefit. Electronic Commerce Research and Applications, 8(3), 130-141.

[38] Lu, Y., Yang, S., Chau, P. Y., \& Cao, Y., (2011). Dynamics between the trust transfer process and intention to use mobile payment services: A cross-environment perspective. Information \& Management, 48(8), 393403.

[39] Luo, X., Li, H., Zhang, J., \& Shim, J. P., (2010). Examining multi-dimensional trust and multi-faceted risk in initial acceptance of emerging technologies: An empirical study of mobile banking services. Decision Support Systems, 49(2), 222-234.

[40] Mahdi, M. O. S. (2011), Trust and security of electronic banking services in Saudi commercial banks: Saudis versus Non Saudis opinions. African Journal of Business Management, 5(14), 5524-5535.

[41] Mallat, N., (2007). Exploring consumer adoption of mobile payments-a qualitative study. The Journal of Strategic Information Systems, 16(4), 413-432.

[42] Mawtani, Ministry of Communications and the evolution of telecommunications networks and the Internet, 23/4/2011. Retrieved on $8 / 2 / 2015$

[43] Mohsen, A. (2010), Factors influencing the customer's choice of electronic banking, a study in a sample of customers banks. Mustansiriya University, pp.1-16.

[44]Nunnally, J.C., \& Bernstein, I.H. (1994),Psychometric theory. McGraw, New York.

[45] Ndubisi, N. O., \& Sinti, Q., (2006). Consumer attitudes, system's characteristics and internet banking adoption in Malaysia. Management Research News, 29(1/2), 16-27.

[46] Nasri,W., (2011). Factors Influencing the Adoption of Internet Banking in Tunisia. International Journal of Business and Management 6(8), 143-160.

[47] Pavlou, P. A., (2003). Consumer acceptance of electronic commerce: integrating trust and risk with the technology acceptance model. International Journal of Electronic Commerce, 7(3), 101-134.

[48] Raman, M., Stephenaus, R., Alam, N., \&Kuppusamy, M., (2008). Information Technology in Malaysia: Eservice quality and Uptake of Internet banking.Journal of Internet Banking and Commerce, 13(2), 1-18.

[49] Sathye,M. (1999), Adoption of internet banking by Australian consumers: an empirical Investigation. International Journal of Bank Marketing, 17(7), 324-334.

[50] Shih, Y. Y., \& Fang, K., (2004), The use of a decomposed theory of planned behavior to study Internet banking in Taiwan. Internet Research, 14(3), 213-223.

[51] Shendi, A., (2011). Patterns and electronic banking options Acceptance and rejection,College of Business and Economics - University of Wasit, Prof. Dr. AdibQasimShendi. Retrieved on 11 March 2012 from: www.iasj.net $/$ iasj?func $=$ fulltext\&aId $=53361$.

[52] Shi, W., Shambare, N., \& Wang, J., (2008), The adoption of internet banking: An institutional theory perspective. Journal of Financial Services Marketing, 12(4), 272-286.

[53] Tan, M., \&Teo, T, (2000), Factors influencing the adoption of Internet banking. Journal of the Association for Information Sciences, 1(5), 1-42.

[54] Thatcher, J. B., \&Perrewe, P. L., (2002), An empirical examination of individual traits as antecedents to computer anxiety and computer self-efficacy. Mis Quarterly, 26(4), 381-396.

[55] Venkatesh, V., Morris, M. G., Davis, G. B., \& Davis, F. D., (2003). User acceptance of information technology: toward a unified view. MIS Quarterly, 27(3), 425-478

[56] Wallis, S., (1997). Financial System Inquiry final report: overview. Sydney, Australia: Australian Government Publishing Service,

[57] Warkentin, M., Gefen, D., Pavlou, P. \& Rose, G. (2002). Encouraging citizen adoption of e- government by building trust. Electronic Markets, 12(3), 157-162.

[58] Yang, S., Lu, Y., Gupta, S., Cao, Y., \& Zhang, R.., (2012), Mobile payment services adoption across time: 
An empirical study of the effects of behavioral beliefs, social influences, and personal traits. Computers in Human Behavior, 28(1), 129-142.

[59] Zmud, R.W. (1979). Individual differences and MIS success: a review of the empirical literature. Management Science, 25(10), 966-979.

\section{APPENDIX: Measurement Scale of Constructs}

\section{Internet Technology Literacy}

1. I feel comfortable when using computers in general.

2. I feel comfortable when using the internet technology.

3. I am satisfied with my current skills for using the internet.

4. I believe computer literate keeps me using internet banking services.

5. I believe Internet literate keeps me using internet banking services.

\section{Resistant to Technology}

6. I am interested to hear about new technological developments.

7. Technological developments have enhanced our lives.

8. I feel comfortable in changing and using internet banking services for my financial activities.

9. I like to experiment with new technologies such as Internet banking services.

\section{Perceived Risk Technology}

10. I believe that money can be easily stolen while using Internet banking.

11. I believe that the decision to transact using IB is risky.

12. I believe that the decision to transact using IB is negative.

13. I am afraid that other people might get access to information about my Internet banking transactions.

\section{Anxiety Technology}

14. I feel nervous about using Internet banking.

15. It scares me to think that I could lose a lot of information using internet banking by hitting the wrong key.

16. I hesitate to use internet banking for fear of making mistakes I cannot correct.

17. The using of internet banking is somewhat intimidating to me.

\section{Information on Technology}

18. I receive enough information about internet banking toward IBSA.

19. I receive enough information about the benefits of internet banking toward IBSA.

20. I receive enough information of using internet banking.

21. 1 am aware of Internet banking and its benefits

\section{Internet Banking Services Adoption (IBSA)}

22. I find internet banking is useful for managing my financial matters.

23. I believe internet banking is an easy way to conduct banking activities.

24. I find that internet banking is encouraging.

25. I feel fast internet access speed is important in internet banking 